Cuthbertson, D. P. (1933). Biochem. F. 27, 1099.

Edsall, J. T. (1930). F. biol. Chem. 89, 289.

Folch, J., Ascoli, I., Lees, M., Meath, J. A. \& le Baron, F. N. (1951). F. biol. Chem. 19r, 833.

Fries, J. A. (1907). Bull. U.S. Bur. Anim. Ind. no. 94.

Köhler, A. (1900-I). Hoppe-Seyl. Z. 31, 479.

Lusk, G. (1931). The Elements of the Science of Nutrition. Philadelphia: W. B. Saunders Co.

Pregl, F. (r924). Quantitative Organic Micro-analysis. London: J. and A. Churchill.

Rubner, M. (1885). Z. Biol. 21, 312.

Schulze, E. \& Reineke, A. (1867). Landw. VersSta. 9, 97.

Stohmann \& Langbein (1891). F. prakt. Chem. (N.F.) 44, 364 (quoted by Armsby, 1917).

\title{
The Cholinesterase Problem in the Newborn Puppy
}

\author{
By R. A. McCANCE AND L. M. BROWN \\ Medical Research Council Department of Experimental Medicine, \\ University of Cambridge
}

(Received 2 February 1952)

McCance, Hutchinson, Dean \& Jones (I949) showed that the pseudo-cholinesterase activity in the serum of the puppy might increase up to twenty-five times its initial value in the first 3 days of life, and decrease again within about ro days. The massive rise was attributed to the absorption of intact molecules of enzyme through the intestinal wall from the mother's colostrum, which exhibited a very high cholinesterase activity. The present study was undertaken $(a)$ to provide some information about the rate of destruction of the colostrum cholinesterase by digestive enzymes of the puppy, adult dog and pig in vitro; and $(b)$ to find out whether the cholinesterase in the serum was taken up by any of the puppy's tissues, thus giving a clue to its function.

\section{METHODS \\ Animals}

Organs from adult dogs that had been killed for experimental purposes in other Departments were obtained immediately after death. Since neither the serum nor the red cells showed any change in cholinesterase activity as a result of these experiments, it is unlikely that the activity of the organs was altered. Fresh pig pancreas and duodenum were obtained from the local slaughterhouse.

Most of the puppies were born in the Department. They were weighed, killed by a blow on the head, decapitated and bled into a centrifuge tube. The organs were removed and prepared for cholinesterase estimations, and samples of pancreas were also taken for preparation of proteolytic enzymes and histological examination.

\section{Digestion experiments}

Preparation of proteolytic enzymes. Pancreas from pigs, adult dogs and newborn puppies was minced or cut up finely with scissors, washed with acetone and ether, allowed to dry at room temperature and then sieved and stored. To obtain enterokinase, the mucosa was scraped from the wall of the duodenum and dried, sieved and stored in the same way as the pancreas. A mixture of intestinal ereptic enzymes was obtained 
by suspending the intestinal mucosa from pigs in five times its volume of $90 \%(\mathrm{v} / \mathrm{v})$ glycerol in water. The extract was stored at $4^{\circ}$.

Dog's colostrum was obtained by manual expression in the last days of pregnancy or very soon after delivery, and its cholinesterase activity was estimated. Samples with an activity of 4000-6000 units/ml. were used (for definition of the unit see p. 93).

Casein or peptone substrates. A $2.5 \%(\mathrm{w} / \mathrm{v})$ solution of casein was prepared by warming $5^{\circ} \mathrm{g}$ Glaxo light white casein with $100 \mathrm{ml}$. water, neutralizing with $0.3 \mathrm{~N}-\mathrm{NaOH}$ and stirring until clear. The solution was heated to boiling point, cooled, made up to $200 \mathrm{ml}$. and stored under toluene. Its total $\mathrm{N}$ was calculated from the weight of the commercial casein after drying at $100^{\circ}$. Oxoid peptone (Oxo Ltd.), $5.0 \mathrm{~g}$, was dissolved in $200 \mathrm{ml}$. water, boiled, cooled and stored in the same way as casein. The total $\mathrm{N}$ was determined by the micro-Kjeldahl technique.

Pancreatic digestion. In the first experiments a suspension of $250 \mathrm{mg}$ dried pancreas was used with $250 \mathrm{mg}$ casein (10 ml. of $2.5 \%(\mathrm{w} / \mathrm{v})$ solution) and $0.1-0.2 \mathrm{ml}$. colostrum. The pH was adjusted to 8.8 , the volume made up to $25 \mathrm{ml}$. and toluene added as a preservative. Samples were taken for estimation of proteolytic and cholinesterase activity before and after a $4 \mathrm{~h}$ period of incubation at $37^{\circ}$. This was satisfactory in organs taken from the pig, but the pancreatic suspensions from dogs and puppies displayed so much cholinesterase activity that it was impossible to study their action on the cholinesterase of colostrum in this way. It was found, however, that the addition of enterokinase preparations, in addition to increasing proteolytic activity, led to the rapid destruction of pancreatic cholinesterase. Accordingly, in later experiments, the dried pancreas of all three types of animal was incubated with $25 \mathrm{mg}$ mucosa in ro $\mathrm{ml}$. water at $\mathrm{pH} 8.8$ and $37^{\circ}$ for $2 \mathrm{~h}$, after which the casein and colostrum were added, the $\mathrm{pH}$ readjusted, the volume made up to $25 \mathrm{ml}$. and the flasks incubated for a further $4 \mathrm{~h}$. Controls were provided by boiling the contents of some flasks after the preliminary $2 \mathrm{~h}$ incubation. Other control flasks contained preparations of mucosa without pancreas, and pancreas and mucosa without colostrum. In the absence of pancreatic tissue, mucosal (enterokinase) extracts displayed no proteolytic activity towards casein or peptone and caused no inactivation of colostrum cholinesterase.

Ereptic digestion. Five ml. glycerol extract of intestinal mucosa, Io $\mathrm{ml} .2 \cdot 5 \%(\mathrm{w} / \mathrm{v})$ Oxoid peptone and $0.1-0.2 \mathrm{ml}$. colostrum in a total volume of $25 \mathrm{ml}$. were incubated for $4 \mathrm{~h}$ at $\mathrm{pH} 7$ and $37^{\circ}$. Controls were provided by boiling the extract.

Proteolytic activity was followed by estimating the increase of amino-N by formol titration. The results are expressed as the percentage of total $\mathrm{N}$ liberated as amino-N.

Cholinesterase activity in the digestion flasks was measured manometrically (Harrison \& Brown, I95I) using acetylcholine chloride (Roche Products Ltd.) as substrate in a final concentration of $0.03 \mathrm{M}$. It was not possible to include non-enzymic controls, but estimations were performed in duplicate in the usual way. In some experiments destruction of colostrum cholinesterase continued during the estimations, and to standardize this the final readings were always taken $45 \mathrm{~min}$ after sampling. Cholinesterase activity after the $4 \mathrm{~h}$ period of digestion is expressed as a percentage of the initial activity. 


\section{Cholinesterase of puppies' organs}

One or two puppies were removed from each litter and killed before they had been suckled; others were allowed to suckle, and the rest were reared by hand for 3 or 4 days on one of the following cholinesterase-free diets: (a) tinned evaporated cow's milk diluted with about one part of water to two of milk; $(b)$ about $20 \mathrm{~g}$ Lactol (dried goat's milk, A. F. Sherley and Co. Ltd.) in $100 \mathrm{ml}$. boiled water; (c) bitch's milk collected by manual expression during full lactation and regression, heated for $\mathrm{I} h$ in a sealed bottle at $100^{\circ}$ and stored at $0^{\circ}$. The puppies were fed every $2 \mathrm{~h}$ during the day and at approximately 4 -hourly intervals during the night. They were allowed to take as much food as they wished. At least $2 \mathrm{~h}$ were allowed to elapse between their last meal and the time when they were killed.

Cholinesterase estimations. Samples of the organs from dogs and puppies were removed immediately after death, washed with $0.9 \%(w / v) ~ \mathrm{NaCl}$, dried with filter paper and homogenized with five to twenty parts distilled water (Folley \& Watson, I948). The homogenates were saturated with toluene and kept at $4^{\circ}$ for a week without loss of activity. Serums kept indefinitely.

Enzyme activity was measured manometrically as described by Harrison \& Brown (195I). Acetylcholine perchlorate (British Drug Houses Ltd.) was used in a final concentration of $0.06 \mathrm{M}$. The perchlorate ion has no effect on the hydrolysis of the ester (Kahane \& Lévy, 1936). The unit of cholinesterase is defined as the amount of enzyme that liberates $\mathrm{I} \mu \mathrm{l} . \mathrm{CO}_{2} / \mathrm{min}$ from acetylcholine.

Histology. Pancreatic tissue was fixed in Heidenhain's 'Susa' fixative and embedded in paraffin. Sections were stained by Ehrlich's haematoxylin and eosin; some were also stained by Goldner's (1938) modification of Masson's trichrome stain. The granules in the acinar cells stained well only in a narrow outer zone of the sections, and there only if the surface was not covered by fat. The fixative employed was probably responsible for this but in any event it does not affect the conclusions for the staining at the surface was excellent.

\section{RESULTS}

\section{Digestion experiments}

Digestion in the stomach. The colostrum cholinesterase was completely inactivated in a few minutes at $\mathrm{pH} 2$ without the action of pepsin. There is, however, some evidence that this need not prevent active cholinesterase reaching the intestine of the puppy, for although the empty stomach of the newborn puppy had a $\mathrm{pH}$ of $2-3$, the contents of a stomach of a day-old puppy that had recently been fed were found to have a $\mathrm{pH}$ of 5 and a cholinesterase activity of $2350 \mathrm{units} / \mathrm{ml}$., which was nearly as high as that of the mother's colostrum. At the higher $\mathrm{pH}$ much cholinesterase from colostrum could have passed through the stomach without destruction, for in most young animals milk begins to leave the stomach as soon as it is full.

Pancreatic enzymes. Preparations of pig's pancreas displayed no cholinesterase activity. On incubation for $4 \mathrm{~h}$ with casein and colostrum, a variable but usually moderate digestion of casein took place, with little or no destruction of the colostrum 
cholinesterase. About $30 \%$ of the amino-N was liberated and $40 \%$ of the colostrum cholinesterase activity destroyed if the pancreatic tissue was incubated for $2 \mathrm{~h}$ before adding the casein and colostrum. This was assumed to be due to a gradual activation of tryptic enzymes. The pancreatic cholinesterase of dogs and puppies was often completely stable under these conditions.

Table I shows the results obtained with pancreatic preparations from the pig, adult dog and puppy, incubated with enterokinase for $2 \mathrm{~h}$ before their action was tested on casein and colostrum. From 30 to $46 \%$ of the amino-N was liberated in

Table I. Liberation of amino- $N$ from casein and destruction of colostrum cholinesterase by pancreatic tissue activated by intestinal mucosa

(Incubation period $4 \mathrm{~h}$ at $37^{\circ}$ after a previous incubation of the pancreas and mucosa for $2 \mathrm{~h}$ )

$\begin{array}{lcc}\text { Animal } & \begin{array}{c}\text { Amino-N } \\ \text { liberated from } \\ \text { I00 mg casein-N } \\ \text { (mg) }\end{array} & \begin{array}{c}\text { Cholinesterase } \\ \text { inactivated, as }\end{array} \\ \begin{array}{c}\text { percentage of } \\ \text { initial activity }\end{array} \\ \text { Dog } & 32 & 91 \\ \text { Dog } & 35 & 68 \\ \text { Puppy } & 46 & 36 \\ \text { Puppy } & 30 & 43 \\ \text { Puppy } & 32 & 50 \\ \text { Pig } & 34 & 80 \\ \text { Pig } & 34 & 35\end{array}$

$4 \mathrm{~h}$ and the cholinesterase activity of the colostrum fell to a variable extent although it never reached zero. In view of the great individual variations observed with pigs it would be unwise to conclude that the tryptic enzymes of the dog are much more deleterious to the cholinesterase than are those of the puppy, but it may be added that the pancreatic cholinesterase of the dog was completely destroyed by incubation with mucosa for $\mathrm{I} h$, whereas that of the puppies sometimes showed a small activity after incubation for $2 \mathrm{~h}$.

Ereptic digestion. Ereptic enzymes of the intestinal mucosa caused a liberation of $23 \%$ of the peptone $\mathrm{N}$ as amino- $\mathrm{N}$, but there was no inactivation of the colostrum cholinesterase.

\section{Cholinesterase activity of the organs of puppies and dogs}

In newborn puppies, in normal suckled puppies 3-4 days old and in adult dogs, the activity of the auricle and ventricle of the heart and of the lung, kidney, small intestine and parotid gland was below 50 units $/ g$, with the exception of the kidney of one puppy on the $4^{\text {th }}$ day in which it was 100 units/g. The activities of the livers were between 200 and 500 units/g, and there was no correlation with age.

The activity of the serum and pancreas of puppies at birth and at 3-4 days of age is shown in Table 2, and that of adult dogs in Table 3. At birth the serum activity varied from 25 to 44 units/ml. and the large increase in the activity of the serum of the puppies suckled by their mothers is in keeping with the findings of McCance et al. (1949). At the age of 4 days the cholinesterase in the serum of the puppy has usually passed its peak and is declining. The serum of puppies reared by hand was as a rule 
no more active than that of puppies at birth or of adult dogs. In a few instances, however, the activity was almost doubled and in one trebled.

The activity of the pancreas at birth ranged from 540 to I $140 \mathrm{units} / \mathrm{g}$, and by the $3^{\text {rd }}$ or $4^{\text {th }}$ day had risen in suckled puppies to an average of 2140 units $/ g$ which is comparable to that of adult dogs. The pancreases of puppies reared by hand showed

Table 2. Cholinesterase activity of the serum and pancreas of puppies at birth and at 3-4 days of age

\begin{tabular}{|c|c|c|c|c|c|c|c|}
\hline \multirow[b]{2}{*}{$\begin{array}{l}\text { Mother's name } \\
\text { and month } \\
\text { of birth }\end{array}$} & \multicolumn{2}{|c|}{ At birth } & \multicolumn{3}{|c|}{ Reared by hand } & \multicolumn{2}{|c|}{ Suckled } \\
\hline & $\begin{array}{c}\text { Serum } \\
\text { (Units/ml.) }\end{array}$ & $\begin{array}{l}\text { Pancreas } \\
\text { (Units/g) }\end{array}$ & Food & $\begin{array}{c}\text { Serum } \\
\text { (Units/ml.) }\end{array}$ & $\begin{array}{l}\text { Pancreas } \\
\text { (Units/g) }\end{array}$ & $\begin{array}{c}\text { Serum } \\
\text { (Units/ml.) }\end{array}$ & $\begin{array}{l}\text { Pancreas } \\
\text { (Units/g) }\end{array}$ \\
\hline Nina, Mar. $195^{\circ}$ & 26 & 740 & - & - & 一 & 123 & 2610 \\
\hline Nina, Nov. $195^{\circ}$ & 40 & 1055. & Evaporated milk & 43 & $46_{5}$ & I 88 & 2150 \\
\hline Blackie, Mar. I95 I & 43 & $1020^{\circ}$ & Lactol & $\{36$ & 510 & 615 & 1150 \\
\hline & 36 & 1125 & & $\left\{\begin{array}{l}52 \\
2\end{array}\right.$ & 615 & - & - \\
\hline & & & & $(92$ & 570 & - & - \\
\hline & & & & 35 & 630 & 212 & 2100 \\
\hline Laura, Apr. I951 & 39 & 770 & Lactol & 42 & 505 & 238 & 2150 \\
\hline & 27 & 875 & & 86 & 755 & 256 & 2720 \\
\hline & & & & 44 & 750 & - & - \\
\hline & & & & $\int 3^{8}$ & I 700 & 273 & 2680 \\
\hline Nina, June $195^{1}$ & 25 & $95^{\circ}$ & Bolled Ditch s milk & $\{45$ & 2230 & 270 & 2750 \\
\hline Blackie, Aug. I95 I & 33 & I I 40 & Boiled bitch's milk & 87 & $245^{\circ}$ & 140 & I 570 \\
\hline Laura, Oct. I95 I & 44 & 820 & $\begin{array}{l}\text { Boiled bitch's milk } \\
\text { Lactol }\end{array}$ & $\begin{array}{l}45 \\
36\end{array}$ & $\begin{array}{l}660 \\
690\end{array}$ & 109 & $\stackrel{1680}{-}$ \\
\hline Nina, Nov. 1951 & $3^{8}$ & 540 & Boiled bitch's milk & $\left\{\begin{array}{l}99 \\
65\end{array}\right.$ & $\begin{array}{r}1060 \\
895\end{array}$ & $\overline{360}$ & $\overline{1760}$ \\
\hline & & & Lactol & $\left\{\begin{array}{l}\text { III } \\
\text { I65 }\end{array}\right.$ & $\begin{array}{r}690 \\
1080\end{array}$ & 320 & 2390 \\
\hline
\end{tabular}

Table 3. Cholinesterase activity of the serum and pancreas of five adult dogs

\begin{tabular}{cc}
$\begin{array}{c}\text { Serum } \\
\text { (Units/ml.) }\end{array}$ & $\begin{array}{c}\text { Pancreas } \\
\text { (Units/g) }\end{array}$ \\
44 & I450 \\
49 & 2570 \\
$\mathbf{5 2}$ & 2000 \\
\hline $\mathbf{3 2}$ & $\mathbf{2 2 4 0}$
\end{tabular}

great variation. Most of the puppies fed on evaporated milk or Lactol had a lower cholinesterase activity than at birth. They did not gain much weight and sometimes had diarrhoea. Puppies from two litters reared on boiled bitch's milk had pancreatic cholinesterase activities similar to those of suckled puppies and adult dogs, but puppies from two other litters had no more cholinesterase activity in their pancreases than those fed on Lactol. All of them were healthy and progressed well, but they grew less rapidly than the suckled puppies.

Histology of the pancreas. In the newborn puppies and in those suckled by the mother the secretory granules were abundant. It is possible that there was a small quantitative difference in the staining affinities of the granules from suckled and unsuckled puppies. In the puppies fed on Lactol, however, the granules were much less abundant and sometimes almost completely absent; the acinar cells appeared 
smaller, the nucleus was nearer to the centre of the cell instead of being right at the base, and the cytoplasm appeared more basophilic. It was impossible to say whether this was due to a real increase in basophilia, or whether it was merely due to the absence of the acidophilic secretory granules. Pancreatic cells from the puppies fed on boiled bitch's milk contained moderate amounts of acidophilic granules. These were less abundant than in the pancreatic cells of the newborn or the suckled puppies, but considerably more numerous than in the cells of those fed on Lactol.

The adipose tissue in the newborn puppies showed a moderate number of small vacuoles in the cytoplasm of the adipose cells, indicating the presence of a small amount of fat. In the puppies suckled by the mother the amount of fat was considerably greater. It was reduced, and sometimes almost completely absent in the puppies fed on Lactol. The appearance of the cells in puppies fed on boiled bitch's milk was intermediate.

\section{DISCUSSION}

The digestion experiments in vitro suggest that, although the cholinesterase in bitch's colostrum was slowly inactivated by the mixture of enzymes in the activated pancreatic preparations, considerable activity remained even after $4 \mathrm{~h}$. The original colostrum had an activity of over 4000 units $/ \mathrm{ml}$, so that if $50 \%$ were destroyed in $4 \mathrm{~h}$ in vivo, 2000 units diluted in an unknown volume might still be present in the gut after ingestion of $\mathrm{I} \mathrm{ml}$. colostrum, assuming that none had been absorbed. It is, however, reasonable to suppose that some of the colostrum cholinesterase would have been absorbed from the gut within that time since it is known that antibodies can be absorbed by the puppy during the first few days of life (Mason, Dalling \& Gordon, I930; Schneider \& Szathmáry, 1939) and the conclusion is entirely in keeping with the results of McCance et al. (1949).

It was at first thought that the increase in the pancreatic activity after birth in suckled puppies was due to the active enzymes absorbed from the gut into the plasma being taken up by the pancreas. At that time the controls were puppies fed on evaporated milk or Lactol. When later it was found that the pancreatic activity in puppies fed on boiled bitch's milk might be much higher than at birth, it became clear that this explanation was impossible. It was then supposed that the rise in pancreatic activity was an indication that puppies were thriving, but this cannot be the whole explanation for some of the puppies reared on Lactol gained a little weight, and one of the most thriving puppies fed on boiled bitch's milk had a very low pancreatic activity at 4 days of age. It is possible that active groups or peptides of the denatured cholinesterase protein in boiled bitch's milk may be set free in the gut and absorbed, and rebuilt to cholinesterase in the pancreas. The bitch's milk had an activity of not more than 100 units $/ \mathrm{ml}$. before being heated at $100^{\circ}$, but cow's and goat's milk have none at all.

The histology shows that the presence of granules in the pancreas is associated with the deposition of fat in the surrounding tissues and a satisfactory gain in weight. These appearances tally with the cholinesterase activity of suckled and Lactol-fed puppies, but it cannot be assumed that the granules consist of cholinesterase proteins 
ready to be secreted, for the glands seem to contain many granules at birth, a time when the cholinesterase activity is low.

These experiments were planned to find a function for the cholinesterase in the colostrum. This object has not been achieved, and it may be that the enzyme has no important function after its ingestion. Cholinesterase appears in the pancreatic juice of the adult dog in large amounts (McCance, Brown, Comline \& Titchen, I95I) and the enzyme in colostrum may carry the young animal over the first day or two of life until the pancreas and the juice which it secretes attain full activity. It is possible, however, to rear puppies quite successfully on boiled bitch's milk for the first 4 days of their lives without the benefit of the enzyme in colostrum. Nothing is yet known of the cholinesterase activity of pancreatic juice in the very young puppy, but presumably it is fairly high, and it is possible that the absorption of some of this enzyme from the gut accounts for the moderate elevation of activity found in the serum of one or two of the puppies fed on inactive milks. One new fact which these experiments seem to have demonstrated is that the cholinesterase activity of the pancreas normally rises considerably in the first 4 days of a puppy's life, and it is natural to relate this to the rise in the activity of cytoplasmic lipase and amylase which takes place in the pancreas of the horse and ox between foetal and adult life (Allfrey, Stern \& Mirsky, 1952).

\section{SUMMARY}

I. The cholinesterase of bitch's colostrum was destroyed at $\mathbf{p H ~} 2$, but much of the colostrum ingested by the puppy probably leaves the stomach while the $\mathrm{pH}$ is well above this figure.

2. The cholinesterase of colostrum was destroyed only slowly in vitro by activated pancreatic enzymes of the adult dog, puppy and pig. It was unaffected by ereptic enzymes.

3. The cholinesterase activity of the pancreas of the puppy increased about threefold between birth and the $3^{\text {rd }}$ or $4^{\text {th }}$ day of life, when puppies were thriving and being suckled by their mothers. It did not increase in this way if the puppies were fed on cow's or goat's milk but it rose to similar levels in some puppies reared by hand on boiled bitch's milk.

4. The histological appearances of the pancreatic granules could be correlated with the nutritional progress of the puppy, but not with the cholinesterase activity of the gland.

5. The cholinesterase of the colostrum and milk of the bitch has not so far been found to have any specific function either before or after its absorption from the gut.

The authors are grateful for the co-operation of other Departments in providing them with the organs of the adult dogs. The histology was entirely the work of Dr A. M. Barrett, and Mrs B. Hines has carried out the work on the last two litters of puppies. Other members of the Department have helped with the night work involved in rearing the puppies. 


\title{
REFERENCES
}

Allfrey, V., Stern, H. \& Mirsky, A. E. (1952). Nature, Lond., 169, I28.

Folley, S. J. \& Watson, S. C. (1948). Biochem. F. 42, 204.

Goldner, J. (1938). Amer. F. Path. 14, 237.

Harrison, M. F. \& Brown, L. M. (1951). Biochem. F. 48, 15 I.

Kahane, E. \& Lévy, J. (1936). Bull. Soc. Chim. biol., Paris, 18, 529.

McCance, R. A., Brown, L. M., Comline, R. S. \& Titchen, D. A. (195 I). Nature, Lond., r68, 788.

McCance, R. A., Hutchinson, A. O., Dean, R. F. A. \& Jones, P. E. H. (1949). Biochem. F. 45, 493.

Mason, J. H., Dalling, T. \& Gordon, W. S. (1930). F. Path. Bact. 33, 783.

Schneider, L. \& Szathmáry, J. (1939). Z. ImmunForsch. 95, 177.

\section{A Radiological Study of the Rate of Passage of Brown and White Bread through the Digestive Tract of Man}

\author{
By R. A. MCCANCE, KATHLEEN M. PRIOR AND ELSIE M. WIDDOWSON \\ Medical Research Council Department of Experimental Medicine, \\ University of Cambridge
}

(Received 6 March 1952)

\begin{abstract}
'Breadde havynge moche branne fylleth the bealye with excrementes and... shortely descendeth from the stomacke' (Elyot, I54I). 'I have known this experience of it, that such as have been costive, by eating browne bread and butter have been made soluble' (Cogan, I 588). 'These effects of wholemeal bread upon the bulk and passage of the faeces, which were common knowledge in the sixteenth century, had been described over I 500 years earlier by Galen and Hippocrates, and all the scientific work that has been carried out in the last 100 years has confirmed them. Increasing the extraction rate of the flour introduces celluloses and hemicelluloses into the diet. These carbohydrates, being fibrous and only incompletely digested and absorbed, increase the calorific value of the faeces. Raising the extraction rate, however, also decreases the 'apparent' digestibility of many of the other constituents of flour (Meyer, I871; Rubner, I883, I9I7; Snyder, I905, I908; Newman, Robinson, Halnan \& Neville, I9r2; McCance \& Walsham, I948-9). The greater amount of nitrogen in the faeces on a brown bread diet was at one time thought to be due to the protein. of the branny fractions not being well digested and absorbed, but from the work of Borgström (r94I), McCance \& Widdowson (1947) and McCance \& Walsham (1948-9) it now seems probable that in man at any rate it is due rather to an increased amount of digestive secretions called forth by the nature of the diet. The digestibility of the fat in wholemeal bread, however, is also very low (McCance \& Walsham, 1948-9), about $40 \%$ of the intake being excreted in the faeces, and since it is unlikely that the digestive juices contain fat, the reason in this instance may be that the lipolytic enzymes do not penetrate freely into the cells of the bran and germ. So far as the inorganic constituents of wheat are concerned, the presence of a large part of the phosphorus in wholemeal in the form of phytates is probably the most important
\end{abstract}

